\title{
LIST OF RARER MOTHS TAKEN IN SHERBORN, MASS.
}

BY E. J. SMITH, NATICK, MASs.

Paonias astylus, June. A few each season.

Estymene prima, June, $2 \sigma^{\top} 1$ ㅇ.

Apantesis rectilinea, May-June-Aug.

" phyllira, middle to last of May.

“ figurata, May, 8-14.

Charadra deridens, May-July.

Raphia frater, June, July.

Harrissimemna trisignata, July 17, one 우.

Baileya doubledayi, July.

Hadenella numuscula, Sept. 11, 1 ㅇ․

Balsa labecula, May 18, one specimen.

Caradrina meralis, Sept. 15, one specimen.

Hadena didonea, July 7 , one 9 .

This was identified by Prof. J. B. Smith who doubted the correctness of locality, as he had never heard of it from Mass., but there is no mistake in the matter. I took it at light.

Hadena leucoscelis, July 27, one.

Macronnoctua onusta, Sept.

Trachea delicata, July 7 , one.

Homohadena badistriga, July 15, one.

Pachnobia monochromatea, May 24, June 25, both $0^{\lambda} \mathrm{s}$.

Porosagrotis tripars, Sept. 14, $10^{\top}$.

Euxoa bostoniensis, 1 + bred. Date lost.

Mamestra rubefacta, June 14-18, 2 ㅇ․

Mamestra goodellii, June-Aug.

“ anguina, June 1, $10^{\top}$.

“ vicina, Sept.

Leucania extincta, June 14, July 1, $10^{\top}-1$ 우.

Taeniocampa culea, June 1.

Xylina tepida, April 16, one sp. on Maple sap.

“ baileyi, March, April, several both sexes on sap.

Tapinostola variana, July 20 .

Fagitana littera, June, July. 
Hydroecia u-album, May, June, Aug.

" speciosissima, Sept.

" rigida, Sept.

“ impecuniosa, Sept.

Conservula anodonta, July 9, one.

Selicanis digitalis, Oct. 2, 6 specimens.

Derrima henrietta, July 31-Aug. 8.

Schinia spinosae, Aug.

" trifascia, July 24, one.

" nundina, Aug.

Autographa rogationis, one. Date lost.

" oxygramma, Sept. 24 , one.

" ou, May 25, one.

" alias, Aug., one.

“ epigaea, Aug. 28, one.

Paectes oculatrix, June 16-July 7.

Exyra rolandiana, July 10, one.

Melanomma auricinctaria, Aug.

Hormisa litophora, July, Aug., several.

" bivittata, July, several.

" orciferalis, June-Sept., several.

Dercetis vitrea, July.

Salia interpuncta, June, July, several.

Apatelodes angelica, July 12, 1 우 .

Hyperaeschra georgica, June, several.

Odontosia elegans, July 11, one.

Janassa lignicolor, Aug.

Schizura apicalis, June 1, one.

Hyparpax aurora, June, several.

Cerura multiscripta, May 19. 1 우.

Fentonia marthesia, June 26, July 8. $1 \sigma^{\top} 1$ 우 .

\section{Geometridae.}

Dyspteris abortivaria, June-Aug., several.

Nyctobia fusifasciata, April 6, one.

Cladora atroliturata, April 21, one.

Lobophora montanata, May 8-31, several. 
Euchoeca cretaceata, May 19-June 5.

Epirrita dilutata, Sept. 9, one.

Eustroma testata, Sept. 4-16.

Mesoleuca vasiliata, April 26-30, 1 pair.

Cosymbia albocostaliata, July 29, $1 \delta^{\top} 2$ 우.

Mr. Swett says this is the only record for the state as far as he knows.

Cinglis purata, Aug., several.

Orthofidonia exornata, June, one.

Sciagraphia continuata, May and Aug., several.

" mellistrigata, June 21, one.

Cymatophora brunneata, June-Aug., several.

Apaecasia deductaria, June 2, one.

Nacophora quernaria, June 14, 1 万.

Plagodis keutzingi, May, several.

“ alcoolaria, June 2-10, $10^{\top}-1$ 우.

“ phlogosaria, July, several.

Gonodontis apiciaria, June, several.

A special meeting of the Entomological Society of America will be held in Boston about the 19th of August next, in connection with the Seventh International Congress of Zoology. Members are urged to be present and to contribute to the program of the meeting.

In order to facilitate the work of the Executive Committee in arranging a program, abstracts of proposed communications should be mailed to the Secretary,

J. Chester Bradley, Berkeley, California. (After July 15th, Cornell University, Ithaca, N. Y.) 

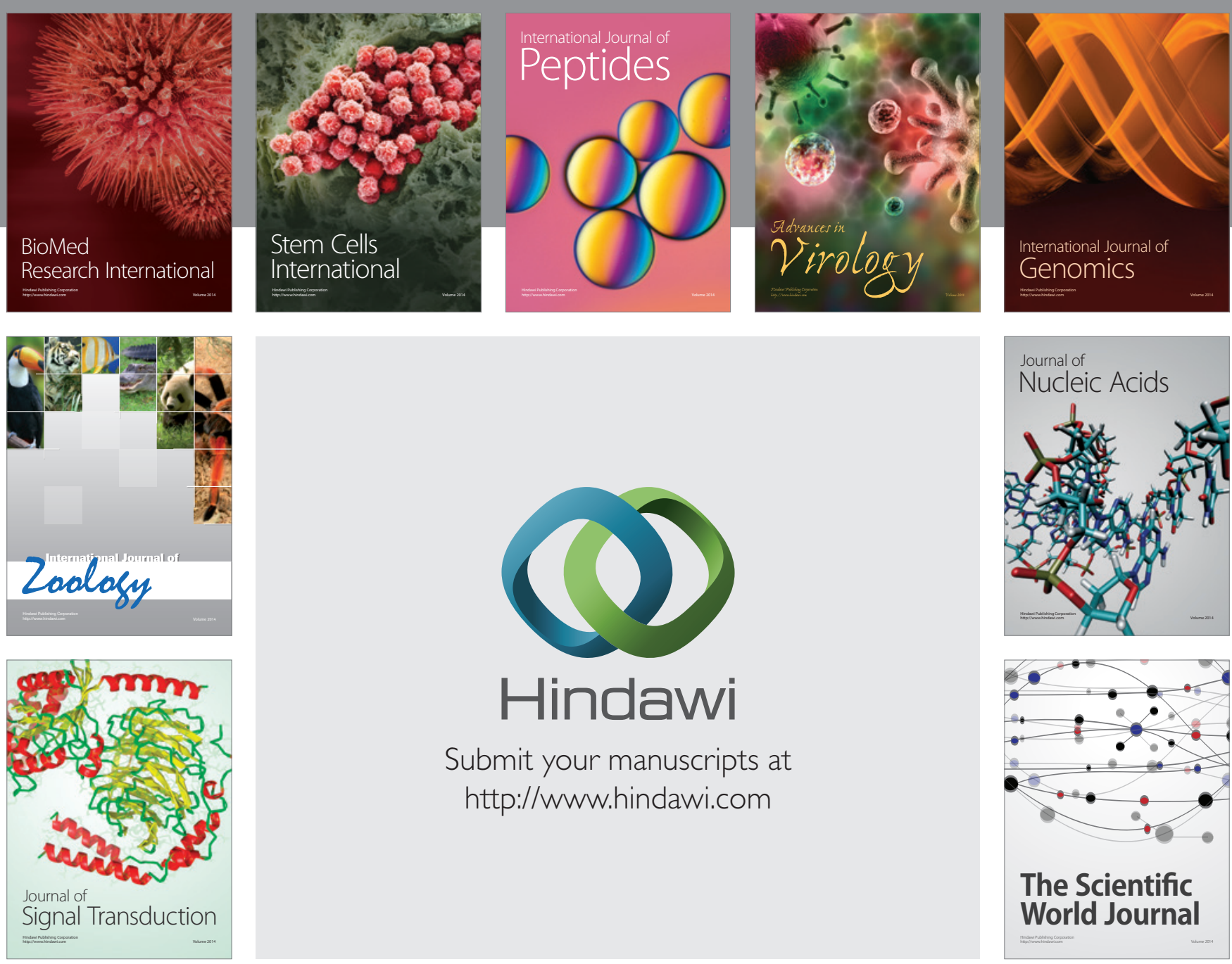

Submit your manuscripts at

http://www.hindawi.com
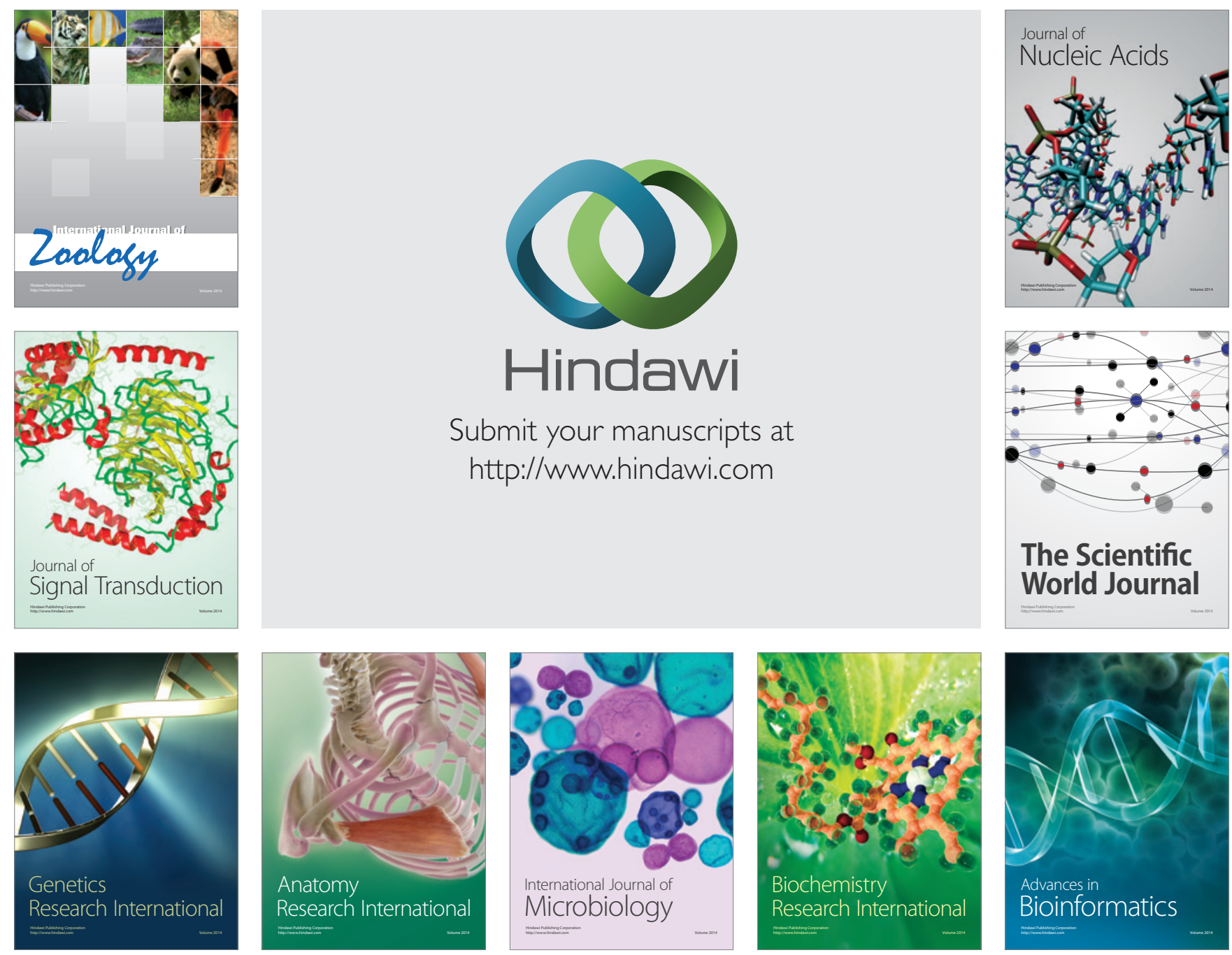

The Scientific World Journal
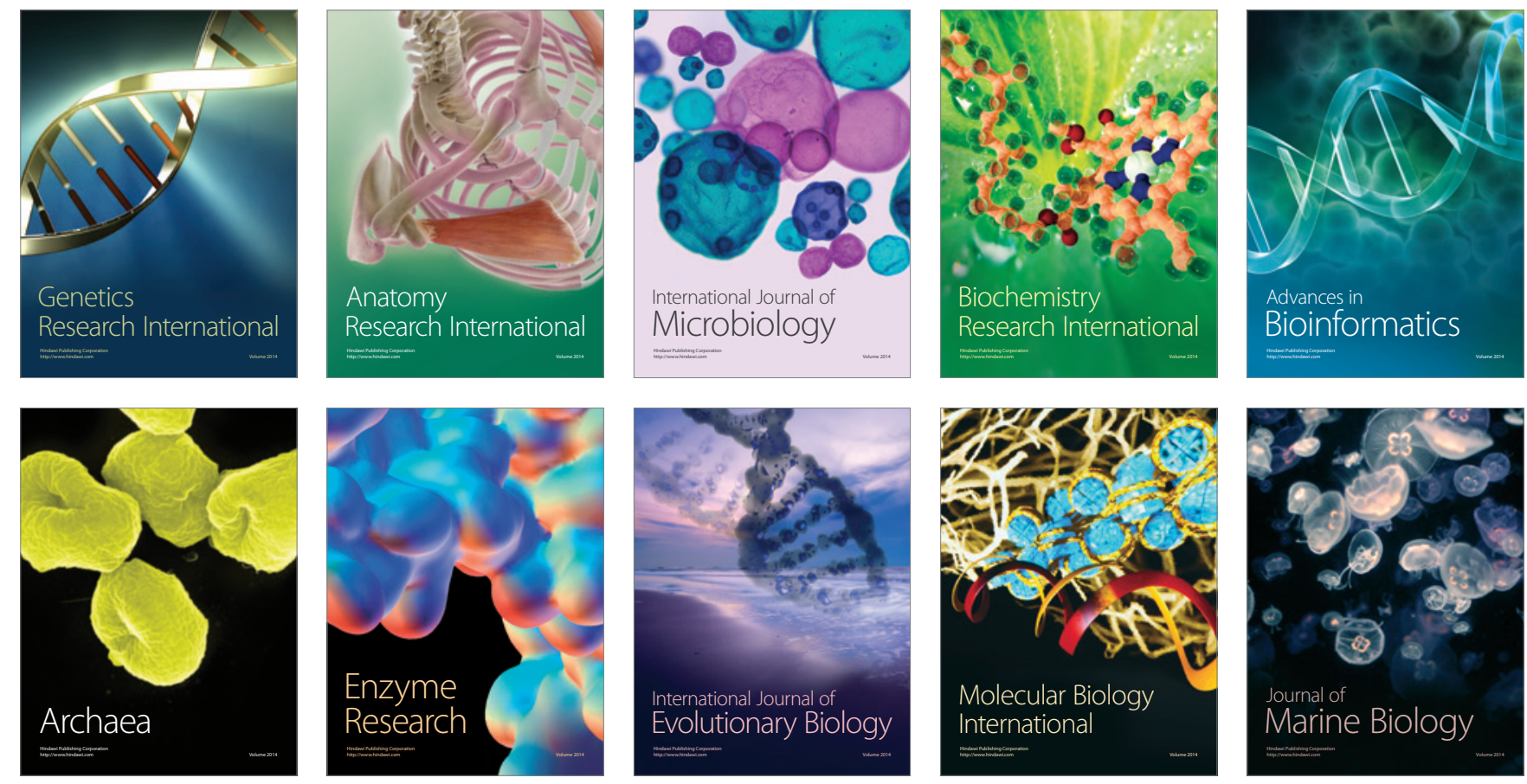